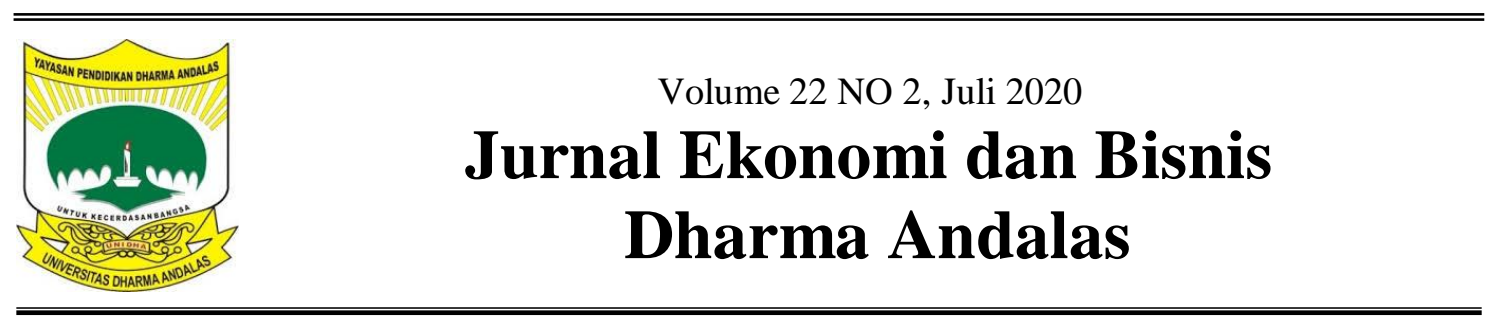

\title{
Analisis Efektivitas dan Kontribusi Pajak Hotel Terhadap Pendapatan Asli Daerah Kota Padang dan Kota Bukittinggi
}

\author{
Nini, Novi Pebriani \\ Fakultas Ekonomi Dan Bisnis Universitas Dharma Andalas ${ }^{1,2}$ \\ niniazwar@gmail.com ${ }^{1}$
}

\begin{abstract}
This study aims to determine the level of hotel tax effectiveness in Padang City and Bukittinggi City, the level of hotel tax growth rate in Padang City and Bukittinggi City, the level of hotel tax contribution for Padang City and Bukittinggi City, and projected hotel tax in Padang City and Bukittinggi in the future. Namely the years 2020 to 2024 and a comparative analysis between the City of Padang and the City of Bukittinggi. The type of research used is descriptive research with quantitative and qualitative approaches. The data source used is secondary data and primary data that is conducting interviews with the Head of the Subdivision of Levies and Other Revenues of the City of Padang Bapenda and the Head of Revenue Section of the Bukittinggi City DPKAD. The results of this study indicate that the level of hotel tax effectiveness in the city of Padang is very effective, and in the city of Bukittinggi the level of hotel tax effectiveness has been effective. While the level of hotel tax growth in Kota Padang and Kota Bukittinggi is still very less in terms of growth, and the level of hotel tax contribution in Padang City is still very less contributing to PAD, and Kota Bukittinggi hotel tax contribution to PAD is said to be less contributing. the level of projection of Padang City and Bukittinggi City has increased from 2020 to 2024
\end{abstract}

Keywords: effectiveness, contribution, hotel taxes, regional original revenue

\begin{abstract}
ABSTRAK
Penelitian ini bertujuan untuk mengetahui tingkat efektivitas pajak hotel Kota Padang dan Kota Bukittinggi, tingkat laju pertumbuhan pajak hotel Kota Padang dan Kota Bukittinggi, tingkat kontribusi pajak hotel Kota Padang dan Kota Bukittinggi, dan proyeksi pajak hotel Kota Padang dan Kota Bukittinggi pada masa yang akan datang yaitu tahun 2020 sampai 2024 serta analisis komparatif antara Kota Padang dan Kota Bukittinggi. Jenis penelitian yang digunakan yaitu penelitian deskriptif dengan pendekatan kuantitatif dan kualitatif. Sumber data yang digunakan adalah data sekunder dan data primer yaitu melakukan wawancara kepada Kepala Subbidang Retribusi Dan Pendapatan Lainnya Bapenda Kota Padang Dan Kepala Seksi Pendapatan DPKAD Kota Bukittinggi. Hasil penelitian menunjukkan bahwa tingkat efektivitas pajak hotel di Kota Padang sangat efektif, dan di Kota Bukittinggi tingkat efektivitas pajak hotel telah efektif. Sedangkan tingkat pertumbuhan pajak hotel Kota Padang dan Kota Bukittinggi masih sangat kurang dari segi pertumbuhan, dan tingkat kontribusi pajak hotel Kota Padang masih sangat kurang berkontribusi terhadap PAD, dan Kota Bukittinggi kontribusi pajak hotel terhadap PAD dikatakan kurang berkontribusi . tingkat proyeksi Kota Padang dan Kota Bukittinggi mengalami peningkatan dari tahun 2020 sampai 2024.
\end{abstract}

Kata Kunci : efektivitas, kontribusi, pajak hotel, pendapatan asli daerah 


\section{PENDAHULUAN}

Otonomi daerah merupakan cara pemerintah untuk mewujudkan pembangunan yang merata di setiap daerah. Dalam melaksanakan berbagai kegiatan yang berkaitan dengan pelaksanaan daerah tentu diperlukan biaya yang cukup besar. Sumber pendapatan yang digunakan dalam pelaksanaan daerah berasal dari bantuan pemerintah pusat dan dari pemerintah daerah itu sendiri. Tetapi, tidak semua sumber pembiayaan pemerintah pusat dapat diberikan kepada daerah, maka dari itu pemerintah daerah diwajibkan untuk dapat menggali segala sumbersumber keuangannya sendiri berdasarkan peraturan perundang-undangan yang berlaku.

Berdasarkan Undang-Undang Nomor 33 Tahun 2004 tentang Perimbangan Keuangan Antara Pemerintah Pusat Dan Pemerintah Daerah, sumber penerimaan daerah yaitu Pendapatan Asli Daerah, Dana Perimbangan, dan Lain-Lain Pendapatan Daerah Yang Sah. Pendapatan asli daerah merupakan suatu indikator keberhasilan dalam penyelenggaraan otonomi daerah. Semakin tinggi PAD maka semakin tinggi kemampuan pemerintah daerah dalam membiayai kebutuhan daerahnya sendiri. Hal ini menunjukkan bahwa pemerintah daerah tersebut telah berhasil dalam menyelenggarakan otonomi daerah(Rabunusa dkk., 2018). Pendapatan asli daerah salah satunya terdiri dari pajak daerah, dimana pajak daerah menjadi salah satu sumber pembiayaan penyelenggaraan pemerintah dan pembangunan daerah. Dengan begitu, penerimaan pajak daerah nantinya dapat memberikan kontribusi terhadap pendapatan asli daerah dalam hal pencapaian dan pemerataan kesejahteraan masyarakat.

Salah satu jenis pajak daerah yang dipungut oleh pemerintah Kota
Padang dan Kota Bukittinggi adalah pajak hotel. Hotel adalah bangunan yang dipakai orang untuk menginap dan dipungut bayaran sesuai dengan Peraturan Daerah Kota Padang Nomor 8 Tahun 2011 tentang Pajak Hotel, dimana objek pajak hotel adalah hotel, pondok pariwisata, losmen pesanggrahan, rumah kos dengan kamar lebih dari 10 (sepuluh), rumah penginapan, dan kegiatan lainnya yang sejenis. Penetapan tarif pajak untuk hotel adalah sebesar $10 \%$, penetapan ini sesuai dengan Undang-Undang Nomor 28 Tahun 2009. Pajak hotel merupakan pajak atas pelayanan yang disediakan oleh hotel yang mempengaruhi Pendapatan Asli Daerah (PAD). Jumlah penerimaan pajak hotel di Kota Padang maupun Kota Bukittinggi dari tahun ke tahun relatif besar, hal ini dapat dilihat pada tabel dibawah ini:

\section{Tabel 1}

Target dan Realisasi Pajak Hotel Kota Padang (dalam rupiah) Tahun 2014-

\begin{tabular}{cccc}
\multicolumn{4}{c}{$\mathbf{c 0 1 8}$} \\
\hline Tahun & $\begin{array}{c}\text { Target Pajak } \\
\text { Hotel }\end{array}$ & $\begin{array}{c}\text { Realisasi Pajak } \\
\text { Hotel }\end{array}$ & $\%$ \\
\hline 2014 & 19.865 .600 .000 & 21.353 .875 .779 & 107,49 \\
2015 & 25.000 .000 .000 & 20.459 .528 .061 & 81,84 \\
2016 & 26.050 .000 .000 & 26.332 .513 .864 & 101,08 \\
2017 & 29.750 .000 .000 & 31.458 .525 .178 & 105,74 \\
2018 & 34.500 .000 .000 & 37.103 .700 .301 & 107,55
\end{tabular}

Sumber: Badan Pendapatan Daerah Kota Padang, 2020

Berdasarkan tabel 1

menunjukkan bahwa realisasi pajak hotel dari tahun 2014 sampai 2018 mengalami kenaikan. Pada tahun 2015 realisasi pajak hotel mengalami penurunan akibat tingginya target yang ditetapkan dari tahun sebelumnya. Realisasi penerimaan pajak hotel yang setiap tahunnya mengalami kenaikan menunjukkan, bahwa pajak hotel sangat berpotensi sebagai sumber pendapatan asli daerah Kota Padang, dan masih bisa dioptimalkan. Untuk itu pemerintah daerah perlu meningkatkan penerimaan 
pajak hotel untuk memperlancar pembangunan daerah.

Tabel 2

Realisasi Pajak Hotel dan PAD Kota Padang (dalam rupiah)Tahun 20142018

\begin{tabular}{ccc}
\hline Tahun & Pajak Hotel & PAD \\
\hline 2014 & 21.353 .875 .779 & 315.678 .797 .930 \\
2015 & 20.459 .528 .061 & $370.413 .732 .165,05$ \\
2016 & 26.332 .513 .864 & $391.925 .662 .646,92$ \\
2017 & 31.458 .525 .178 & $456.295 .916 .658,03$ \\
2018 & 37.103 .700 .301 & $487.655 .433 .745,61$ \\
\hline
\end{tabular}

Sumber: Badan Pendapatan Daerah Kota Padang, 2020

Tabel 2 menunjukkan bahwa realisasi Pendapatan Asli Daerah (PAD) Kota Padang pada tahun 2014 sampai 2017 mengalami kenaikan, tetapi pada tahun 2018 Pendapatan Asli Daerah (PAD) mengalami penurunan. Pendapatan Asli Daerah (PAD) merupakan penerimaan yang diperoleh dari sumber-sumber dalam wilayahnya sendiri yang dipungut berdasarkan peraturan perundang-undangan yang berlaku (Halim, 2001). Untuk itu pemerintah daerah Kota Padang harus terus meningkatkan sumber-sumber PAD, salah satunya dalam hal peningkatan pajak hotel.

Tabel 3

Target dan Realisasi Penerimaan Pajak Hotel Kota Bukittinggi (dalam rupiah)Tahun 2014-2018

\begin{tabular}{cccc}
\hline Tahun & $\begin{array}{c}\text { Target Pajak } \\
\text { Hotel }\end{array}$ & $\begin{array}{c}\text { Realisasi Pajak } \\
\text { Hotel }\end{array}$ & $\%$ \\
\hline 2014 & 9.016 .000 .000 & 8.609 .195 .161 & 95,49 \\
2015 & 9.016 .000 .000 & 9.061 .818 .042 & 100,51 \\
2016 & 12.679 .189 .563 & 10.332 .160 .754 & 81,49 \\
2017 & 14.779 .000 .000 & 12.648 .113 .302 & 85,58 \\
2018 & 14.779 .000 .000 & 13.819 .121 .537 & 93,51 \\
\hline
\end{tabular}

Sumber : Badan Pendapatan Daerah Kota Bukittinggi

Tabel 3 dapat dilihat bahwa realisasi pajak hotel di Kota Bukittinggi dari tahun 2014 sampai 2018 mengalami kenaikan. Hanya pada tahun 2015 target pajak hotel dapat tercapai,dan untuk tahun yang lain target untuk pajak hotel tidak dapat tercapai akibat tingginya target pajak hotel yang ditetapkan. Realisasi penerimaan pajak hotel yang setiap tahunnya mengalami kenaikan menunjukkan, bahwa pajak hotel sangat berpotensi sebagai sumber pendapatan asli daerah Kota Bukittinggi, dan masih bisa dioptimalkan sehingga target penerimaan pajak hotel dapat dicapai. Untuk itu pemerintah daerah perlu meningkatkan penerimaan pajak hotel, supaya penerimaan pemerintah terus meningkat sehingga dapat memperlancar pembangunan daerah.

\section{Tabel 4}

\section{Realisasi Pajak Hotel dan PAD Kota Bukittinggi}

(dalam rupiah)Tahun 2014-2018

\begin{tabular}{ccc}
\hline Tahun & Pajak Hotel & PAD \\
\hline 2014 & 8.609 .195 .161 & 61.613 .681 .043 \\
2015 & 9.061 .818 .042 & $66.027 .359 .716,34$ \\
2016 & 10.332 .160 .754 & $71.303 .771 .735,85$ \\
2017 & 12.648 .113 .302 & $106.147 .934 .380,69$ \\
2018 & 13.819 .121 .537 & $101.935 .592 .226,61$ \\
\hline
\end{tabular}

Sumber : Badan Pendapatan Daerah Kota

Bukittinggi

Tabel 4 menunjukkan bahwa realisasi Pendapatan Asli Daerah (PAD) Kota Bukittinggi pada tahun 2014 sampai 2017 mengalami kenaikan, tetapi pada tahun 2018 Pendapatan Asli Daerah (PAD) mengalami penurunan. Pendapatan Asli Daerah (PAD) merupakan penerimaan yang diperoleh dari sumber-sumber dalam wilayahnya sendiri yang dipungut berdasarkan peraturan perundang-undangan yang berlaku (Halim, 2001). Untuk itu pemerintah daerah Kota Bukittinggi harus terus meningkatkan sumbersumber PAD, salah satunya dalam hal peningkatan pajak hotel.

Pajak hotel ikut berperan dalam meningkatkan penerimaan pendapatan asli daerah Kota Padang dan Kota Bukittinggi. Hal ini, bisa dilihat dari banyaknya pembangunan yang dilakukan oleh pemerintah Kota 
Padangdan Kota Bukittinggi mengenai industri hotel. Dibawah ini data mengenai jumlah hotel yang ada di Kota Padang dan Kota Bukittinggi.

Tabel 5

Jumlah Akomodasi Hotel Menurut Klasifikasi Hotel di Kota Padang dan Kota Bukittinggi Tahun 2014-2018

\begin{tabular}{ccc}
\hline Tahun & Kota Padang & Kota Bukittinggi \\
\hline 2014 & 72 & 67 \\
2015 & 77 & 66 \\
2016 & 91 & 66 \\
2017 & 94 & 75 \\
2018 & 108 & 75 \\
\hline
\end{tabular}

Sumber : BPS Provinsi Sumatera Barat

Tabel 5 diatas, dapat disimpulkan bahwa jumlah hotel di Kota Padang dari tahun 2014 sampai tahun 2018 mengalami kenaikan jumlah hotel, yaitu yang paling pesat terjadi pada tahun 2018 sebesar 108 hotel. Hal ini membuktikan bahwa banyaknya pembangunan industri hotel di Kota Padang didukung dengan banyaknya wisatawan yang datang ke Kota Padang, tidak hanya untuk berwisata tetapi juga untuk menginap serta beristirahat. Jumlah hotel di Kota Bukittinggi dari tahun 2014-2018 mengalamitingkat fluktuasi. Jadi, dapat disimpulkan bahwa Kota Padang lebih berpotensiterhadap penerimaan pajak hotel dibandingkan dengan Kota Bukittinggi. Ditandai dengan lebih banyaknya jumlah hotel di Kota Padang.

Penelitian ini merupakan replika dari penelitianArdiles (2015) yang meneliti tentang Analisis Potensi dan Kontribusi Pajak Hotel Terhadap Pendapatan Asli Daerah Pemerintah Kota Padang 2008 sampai 2014, tetapi yang membedakannya adalah tahun serta ruang lingkup dalam penelitian penulis. Peneliti mengambil ruang lingkup yaitu Kota Padang dan Kota Bukittinggi, dikarenakan lebih banyaknya jumlah hotel yang ada di Kota Padang dan Kota Bukittinggi dibandingkan dengan kotakota lain yang ada di Provinsi Sumatera
Barat serta jumlah wisatawan yang datang ke Kota Padang dan Kota Bukittinggi lebih banyak dan mengalami peningkatan setiap tahunnya dibandingkan dengan kota-kota lain yang ada di Provinsi Sumatera Barat. Penelitian ini bertujuan untuk mengetahui besar realisasi pajak hotel yang dapat dipungut oleh pemerintah setempat dengan efektif sesuai dengan target yang telah ditetapkan, dan untuk mengetahui besarnya kontribusi penerimaan pajak hotel terhadap penerimaan PAD Kota Padang dan Kota Bukittinggi.

Tujuan penelitian yang berhubungan dengan uraian yang telah diungkapkan diatas adalah sebagai berikut : (1) Untuk mengetahui tingkat efektivitas penerimaan pajak hotel di Kota Padang dan Kota Bukittinggi (2014-2018); (2)Untuk mengetahui laju pertumbuhan pajak hotel di Kota Padang dan Kota Bukittinggi (2014-2018); (3) Untuk mengetahui kontribusi penerimaan pajak hotel terhadap PAD Kota Padang dan Kota Bukittinggi (2014-2018); (4)Untuk mengetahui proyeksi penerimaan pajak hotel untuk masa yang akan datang di Kota Padang dan Kota Bukittinggi (2020-2025); (5)Untuk mengetahui analisis komparatif pajak hotel di Kota Padang dengan Kota Bukittinggi (2014-2018).

\section{Pengertian Pajak}

Pangerapan dkk.

mendefinisikan pajak ialah pungutan wajib yang dibayar rakyat untuk negara dan akan digunakan untuk kepentingan pemerintah daerah. Pajak adalah peralihan kekayaan dari pihak rakyat kepada kas negara untuk membiayai pengeluaran rutin dan "surplus"nya digunakan untuk membiayai public investment (Resmi, 2016). Pajak yaitu salah satu sumber dari sekian banyak sumber penerimaan pemerintah daerah yang digunakan untuk membiayai pembangunan di daerah yang bertujuan 
untuk membiayai dan memajukan daerah yang ditempuh dengan kebijakan pada pengoptimalisasian penerimaan pajak, dimana setiap orang wajib membayar pajak sesuai dengan kewajibannya (Toding, 2016). Dari berbagai definisi diatas dapat ditarik kesimpulan bahwa pajak adalah iuran rakyat yang dapat dipaksakan menurut Undang-Undang dan dipungut oleh pemerintah guna untuk memenuhi kesejahteraan rakyat.

\section{Fungsi Pajak}

Menurut Resmi (2016) terdapat 2

(dua) fungsi pajak, yaitu fungsi budgetair dan fungsi regularend

\section{Fungsi Budgetair}

Pada fungsi ini pajak sebagai sumber dana bagi pemerintahan digunakan untuk membiayai pengeluaranbaik rutin maupun pembangunan. Sebagai sumber keuagan negara, pemerintah berupaya memasukkan uang sebanyak-banyaknya ke kas negara.

\section{Fungsi Regulerend (Mengatur)}

Pada fungsi ini pajak sebagai alat untuk mengatur serta melaksanakan kebijaksanaan pemerintah dalam bidang sosial dan ekonomi, dan mencapai tujuan diluar bidang keuangan.

\section{Teori Pemungutan Pajak}

Teori yang mendukung hak negara untuk memungut pajak dari rakyatnya, antara lain (Resmi, 2016):

\section{Teori Asuransi}

Teori ini mengatakan bahwa negara bertugas melindungi orang dengan segala kepentingannya, meliputi keselamatan dan keamanan jiwa, dan juga harta bendanya.

\section{Teori Kepentingan.}

Teori ini hanya memperhatikan pembagian beban pajak yang harus dipungut dari seluruh masyarakat. Pembagian beban ini didasarkan pada kepentingan masing-masing orang dalam tugas pemerintah, termasuk perlindungan atas jiwa orang-orang itu beserta harta bendanya.

\section{a. Teori Gaya Pikul}

Teori ini mengatakan bahwa dasar keadilan pemungutan pajak dilihat dari jasa yang diberikan oleh negara kepada warganya, yaitu perlindungan atas jiwa dan harta bendanya. Gaya pikul seseorang diukur dari besarnya penghasilan dengan memperhitungkan besarnya pengeluaran pembelanjaan seseorang.

b. Teori Kewajiban Pajak Mutlak (Teori Bakti)

Teori ini berlandaskan kepada paham argnische staatsleer yaitu mengajarkan dengan adanya sifat suatu negara maka timbullah hak mutlak untuk memungut pajak.

c. Teori Asas Gaya Beli

Teori ini tidak mempermasalahkan asal mula negara memungut pajak, tetapi melihat pada efeknya, dan memandang efek yang baik itu sebagai dasar keadilan.

\section{Jenis Pajak}

Pajak dapat dikelompokkan menjadi 3 (tiga) kelompok (Resmi, 2016):

Menurut Golongan. Pajak dikelompokkan menjadi 2 (dua) yaitu :

a. Pajak Langsung. Pajak yang harus ditanggung sendiri oleh wajib pajak dan tidak dapat dilimpahkan ke pihak lain. Pajak harus menjadi beban wajib pajak yang bersangkutan. Contoh: Pajak Penghasilan (PPh).

b. Pajak Tidak Langsung. Pajak yang pada akhirnya dapat dibebankan atau dilimpahkan kepada orang lain. Pajak tidak langsung terjadi karena adanya kegiatan, peristiwa, atau perbuatan yang menyebabkan terutangnya pajak, misalnya terjadi penyerahan barang atau jasa. Contoh: Pajak Pertambahan Nilai (PPN).

Menurut Sifat. Pajak dapat dikelompokkan menjadi 2 (dua) yaitu :
a. Pajak Subjektif. Pajak yang didasarkan pada keadaan pribadi wajib pajak atau pengenaan pajak yang 
memperhatikan keadaan subjeknya. Contoh: Pajak Penghasilan (PPh).

b. Pajak Objektif. Pajak yang pengenaannya memperhatikan objeknya baik berupa benda, keadaan, perbuatan, atau peristiwa yang mengakibatkan timbulnya kewajiban dalam membayar pajak, tanpa memperhatikan keadaan pribadi wajib pajak maupun tempat tinggal.

Menurut Lembaga Pemungut. Pajak dikelompokkan menjadi 2(dua) yaitu :

a. Pajak Negara (Pajak Pusat ). Pajak yang dipungut oleh pemerintah pusat dan pada umumnya digunakan untuk membiayai rumah tangga negara. Contoh: PPh, PPN, PPnBM, dan Bea Materai.

b. Pajak Daerah. Pajak yang dipungut oleh pemerintah daerah baik daerah tingkat I (pajak provinsi) maupun daerah tingkat II (pajak kabupaten/kota) dan digunakan untuk membiayai rumah tangga masingmasing daerah.

\section{Asas Pemungutan Pajak}

Resmi (2016) menjelaskan 3 (tiga) asas pemungutan pajak yaitu :

1. Asas Domisili. Negara berhak mengenakan pajak atas seluruh penghasilan wajib pajak yang bertempat tinggal di wilayahnya, baik itu penghasilan yang berada dalam negeri maupun diluar negeri.

2. Asas Sumber. Negara berhak mengenakan pajak atas seluruh penghasilan wajib pajak yang bersumber di wilayahnya, tanpa memperhatikan tempat tinggal wajib pajak. Misalnya, tenaga kerja asing yang bekerja di Indonesia maka dari penghasilan yang didapat di Indonesia akan dikenakan pajak oleh pemerintah Indonesia.

3. Asas Kebangsaan. Pengenaan pajak dihubungkan dengan kebangsaan suatu negara. Asas ini berlandasan pada status kewarganegaraan dari orang atau badan yang memperoleh penghasilan. Misalnya, pajak bangsa asing di Indonesia dikenakan atas setiap orang asing yang bukan berkebangsaan Indonesia tetapi bertempat tinggal di Indonesia.

\section{Sistem Pemungutan Pajak}

Resmi (2016) menjelaskan tentang sistem pemungutan pajak yang dapat dibagi menjadi 3 (tiga) yaitu :

1. Official Assessment System. Sistem pemungutan pajak yang memberikan kewenangan kepada aparatur perpajakan dalam menentukan sendiri jumlah pajak yang terutang setiap tahunnya, sesuai dengan peraturan perundang-undangan perpajakan yang berlaku.

2. Self Assessment System. Sistem pemungutan pajak yang memberikankewenangan kepada wajib pajak dalam menentukan sendiri jumlah pajak yang terutang setiap tahunnya sesuai dengan peraturan perundang-undangan perpajakan yang berlaku. Wajib pajak dianggap mampu menghitung pajak, memahami undang-undang perpajakan yang sedang berlaku, dan mempunyai kejujuran yang tinggi, serta menyadari arti penting dalam membayar pajak.
3. With Holding System. Sistem pemungutan pajak yang memberikankewenangan kepada pihak ketiga yang ditunjuk untuk menentukan besarnya pajak yang terutang oleh wajib pajak, sesuai dengan peraturan perundang- undangan perpajakan yang berlaku.

\section{Syarat Pemungutan Pajak}

Agar pemungutan pajak tidak menimbulkan hambatan atau perlawanan, maka pemungutan pajak harus memenuhi syarat (Putra, 2017)sebagai berikut:

1. Syarat Keadilan. Dengan adanya tujuan hukum maka pelaksanaan dalam pemungutan pajak harus adil, yakni pengenaan pajak harus umum 
dan merata serta disesuaikan dengan kemampuan wajib pajak.

2. Syarat Yuridis. Pajak diatur dalam UUD 1945 pasal 23 ayat 2, yang memberikan jaminan hukum untuk menyatakan keadilan, baik bagi negara maupun warganya.

3. Syarat Ekonomis. Dalam hal pemungutan pajak tidak boleh mengganggu kelancaran kegiatan produksi maupun perdagangan, sehingga tidak menimbulkan kelesuan perekonomian masyarakat.

4. Syarat Finansial. Sesuai dengan fungsi budgetair, dimana biaya pemungutan pajak harus lebih rendah dari hasil pemungutannya.

5. Syarat Sosiologis. Dalam hal pemungutan pajak, sistem yang digunakan haruslah sederhana sehingga akan memudahkan dan mendorong masyarakat dalam memenuhi kewajiban perpajakannya.

\section{Stelsel Pemungutan Pajak}

Menurut Resmi (2016) dalam pemungutan pajak terdapat 3 (tiga) stelsel pajak, yaitu:

1. Stelsel Nyata. Pajak didasarkan pada objek yang sebenarnya. Oleh karena itu, pemungutan pajak baru dapat dilakukan pada akhir tahun pajak, yaitu setelah semua penghasilan yang sesungguhnya dalam suatu tahun pajak diketahui.

2. Stelsel Anggapan (Fiktif). Pajak didasarkan pada suatu anggapan yang diatur oleh undang-undang. Sebagai contoh, penghasilan suatu tahun di anggap sama dengan penghasilan tahun sebelumnya, sehingga pajak yang terutang pada suatu tahun dianggap sama dengan pajak yang terutang pada tahun sebelumnya. Dengan stelsel ini,berarti besarnya pajak yang terutang pada tahun berjalan sudah dapat ditetapkan atau diketahui pada awal tahun yang bersangkutan.
3. Stelsel Campuran. Bahwa pajak didasarkan pada kombinasi antara stelsel nyata dengan stelsel anggapan.

\section{Pajak Daerah}

\section{Pengertian Pajak Daerah}

Pajak daerah ialah kontribusi wajib yang disetorkan oleh warga negara disuatu daerah tertentu yang akan digunakan oleh pemerintah daerah untuk membiayai keperluan rumah tangganya, guna mendukung kemakmuran rakyat yang berdomisili di daerah tersebut (Toding, 2016). Pajak daerah merupakan sumber pendapatan potensial dan memegang peranan penting dalam peningkatan PAD disamping sumber pendapatan daerah lainnya.

Undang-Undang Nomor 28 Tahun 2009 menyatakan pajak yaitu kontribusi wajib kepada daerah oleh orang pribadi atau badan yang bersifat memaksa berdasarkan undang-undang, dan tidak mendapatkan imbalan secara langsung dan digunakan untuk keperluan daerah bagi kemakmuran rakyat. Dari pengertian diatas dapat disimpulkan bahwa pajak derah merupakan iuran wajib oleh wajib pajak baik orang pribadi ataupun badan kepada daerah yang telah diatur dalam undang-undang dan hasilnya digunakan untuk kegiatan pembangunan daerah demi terciptanya masyarakat yang makmur dan sejahtera.

\section{Jenis-jenis Pajak Daerah}

Pajak daerah yang diatur dalam Undang-Undang Nomor 28 Tahun 2009 adalah sebagai berikut :

Pajak provinsi terdiri dari :

a. Pajak Kendaraan Bermotor.

b. Bea Balik Nama Kendaraan Bermotor.

c. Pajak Bahan Bakar Kendaraan

Bermotor.

d. Pajak Air Permukaan

e. Pajak Rokok

Pajak kabupaten/kota terdiri dari :
a. Pajak Hotel
b. Pajak Restoran
c. Pajak Hiburan
d. Pajak Reklame 
e. Pajak Penerangan Jalan

f. Pajak Mineral Bukan Logam Dan Batuan

g. Pajak Parkir

h. Pajak Air Tanah

i. Pajak Sarang Burung Walet

j. Pajak Bumi Dan Bangunan Perdesaan Dan Perkotaan

k. Pajak Perolehan Hak Atas Tanah Dan Bangunan

Dari jenis-jenis pajak daerah diatas tidak mutlak ada disetiap daerah kabupaten/kota di Indonesia. Hal ini berkaitan dengan kewenangan yang diberikan kepada pemerintah daerah untuk dapat dipungut pada suatu daerah, pemerintah daerah harus terlebih dahulu menerbitkan peraturan daerah tentang Pajak Daerah, yang akan menjadi landasan hukum operasional dalam teknis pelaksanaan pengenaan dan pemungutan pajak daerah yang bersangkutan.

\section{Tarif Pajak Daerah}

Tarif maksimal yang ditetapkan oleh Undang-Undang Nomor 34 Tahun 2000 adalah sebagai berikut :

\section{Tabel 6}

Tarif Maksimal Atas Pajak Provinsi Dan Pajak Kota/Kabupaten

\begin{tabular}{|c|c|c|}
\hline Keterangan & Jenis & Tarif \\
\hline \multirow[t]{6}{*}{ Pajak Provinsi } & Pajak Kendaraan Bermotor & $5 \%$ \\
\hline & Bea Balik Nama Kendaraan Bermotor & $10 \%$ \\
\hline & Pajak Bahan Bakar Kendaraan & $5 \%$ \\
\hline & Bermotor & \\
\hline & Pajak Air Permukaan & $20 \%$ \\
\hline & Pajak Rokok & $10 \%$ \\
\hline \multirow{9}{*}{$\begin{array}{l}\text { Pajak } \\
\text { Kabupaten/K } \\
\text { ota }\end{array}$} & Pajak Hotel & $10 \%$ \\
\hline & Pajak Restoran & $10 \%$ \\
\hline & Pajak Hiburan & $35 \%$ \\
\hline & Pajak Reklame & $25 \%$ \\
\hline & Pajak Penerangan Jalan & $10 \%$ \\
\hline & Pajak Parkir & $30 \%$ \\
\hline & Pajak Air Tanah & $20 \%$ \\
\hline & Pajak Sarang Burung Walet & $10 \%$ \\
\hline & $\begin{array}{l}\text { Pajak Perolehan Hak Atas Tanah Dan } \\
\text { Bangunan }\end{array}$ & $5 \%$ \\
\hline
\end{tabular}

\begin{tabular}{lll}
\hline Keterangan & \multicolumn{1}{c}{ Jenis } & Tarif \\
\hline & $\begin{array}{l}\text { Pajak Bumi Dan Bangunan Perdesaan } \\
\text { Dan Perkotaan }\end{array}$ & $30 \%$ \\
\hline Sumber : Undang-Undang Nomor 34 Tahun
\end{tabular}

Sumber : Undang-Undang Nomor 34 Tahun 2000

Pemerintah daerah baik provinsi maupun kabupaten/kota wajib mentaati ketentuan tarif maksimal pajak seperti yang tertera diatas. Untuk pelaksanaannya, pemerintah daerah perlu mengaturnya dalam Peraturan Daerah, berapa tarif minimum dan maksimum untuk masing-masing objek pajak. Besarnya tarif yang berlaku definitif untuk pajak ditetapkan dengan Peraturan Daerah, namun tidak boleh tinggi dari tarif maksimum yang telah ditentukan dalam UU.

\section{Pajak Hotel}

Pajak merupakan sumber keuangan dari daerah termasuk di dalamnya Pajak Hotel. Undang-Undang Nomor 28 Tahun 2009 Pasal 1 angka 20 dan 21, Pajak Hotel adalah pajak daerah atas pelayanan yang disediakan oleh hotel. Menurut Rabunusa dkk. (2018) Pajak hotel ialah pajak atas pelayanan hotel. Hotel merupakan bangunan yang khusus disediakan bagi orang untuk menginap atau beristirahat, memperoleh pelayanan, dan fasilitas lainnya dengan dipungut bayaran.

Pemerintah daerah berhak mengenakan pungutan terhadap masyarakat. Undang-Undang Pemungutan pajak hotel harus didasarkan pada Peraturan Daerah. Peraturan daerah tentang pajak hotel memberikan kepastian hukum mengenai objek pajak, subjek dan wajib pajak, dasar pengenaan tarif dan cara menghitung pajak. Selain itu, sanksi dan hukuman bagi setiap pelanggaran pajak juga diatur dalam peraturan daerah tersebut. Peraturan Daerah Kota Padang Nomor 8 Tahun 2011 tentang pajak daerah menyebutkan yang termasuk dalam objek pajak hotel adalah :

a. Hotel 
b. Pondok pariwisata

c. Losmen

d. Pesanggrahan

e. Rumah kost dengan kamar lebih dari 10 (sepuluh)

f. Rumah penginapan

g. Kegiatan usaha lainnya yang sejenis.

Sedangkan untuk jasa-jasa

lainnya yang tidak termasuk dalam golongan objek pajak hotel antara lain :

a. Jasa tempat tinggal asrama yang diselenggarakan oleh pemerintah, atau pemerintah daerah

b. Jasa sewa apartemen, kondominium dan sejenisnya yang digunakan sebagai tempat tinggal

c. Jasa tempat tinggal di psat pendidikan atau kegiatan keagamaan.

d. Jasa tempat tinggal di rumah sakit, asrama perawat, panti jompo, panti asuan dan panti sosial lainnya yang sejenis

e. Jasa biro perjalanan atau perjalanan wisata yang diselenggarakan oleh hotel yang dapat dimanfaatkan oleh umum.

Subjek pajak hotel adalah orang pribadi atau badan yang melakukan pembayaran kepada orang pribadi atau badan yang mengusahakan hotel, sedangkan wajib pajak hotel adalah orang pribadi atau badan yang mengusahakan hotel. Dasar pengenaan pajak hotel adalah jumlah pembayaran atau yang seharusnya dibayar kepada hotel. Mengenai tarif pajak hotel ditetapkan sebesar $10 \%$ (sepuluh persen).

Menurut Roziana

efektivitas adalah suatu ukuran dalam menghitung berhasil atau tidaknya suatu organisasi dalam mencapai tujuannya. Apabila organisasi berhasil mencapai tujuan, maka organisasi tersebut dapat dikatakan telah berjalan dengan efektif. Sedangkan menurut Syafitri (2016) efektivitas merupakan gambaran dari kemampuan pemerintah daerah dalam merealisasikan PAD dan komponen- komponen PAD yang direncanakan dibandingkan dengan target yang ditetapkan berdasarkan potensi riil daerah.

\section{Kontribusi}

Kontribusi merupakan sumbangan, sokongan atau dukungan terhadap suatu kegiatan. Kontribusi adalah suatu ukuran untuk mengetahui seberapa besar sumbangan pajak daerah dalam meningkatkan Pendapatan asli daerah. Dalam mengetahui kontribusi dilakukan dengan cara membandingkan penerimaan pajak daerah periode tertentu dengan penerimaan PAD periode tertentu pula (Ardiles, 2015). Menurut Syafitri (2016) kontribusi daerah ialah seberapa besar pengaruh atau peran penerimaan pajak daerah dan retribusi daerah terhadap pendapatan asli daerah.

\section{Pendapatan Asli Daerah}

Pengertian Pendapatan Asli Daerah

Setiap daerah harus dapat mengatur rumah tangganya sendiri termasuk dalam urusan pendanaan yang diperlukan daerah untuk melakukan pembangunan, untuk itulah diperlukan sumber-sumber keuangan daerah. Sumber keuangan yang berasal dari dalam daerah itu sendiri disebut pendapatan asli daerah. Pendapatan asli daerah bertujuan untuk memberikan kewenangan kepada pemerintah daerah untuk mendanai pelaksanaan otonomi daerah sesuai dengan potensi yang dimiliki.

Pendapatan asli daerah merupakan salah satu komponen sumber penerimaan daerah selain penerimaan dana transfer, dan lain-lain pendapatan yang sah. (Fitra, 2016). Menurut Undang-Undang Nomor 33 Tahun 2004 tentang Perimbangan Keuangan Antara Pusat Dan Daerah, bahwa pembangunan daerah merupakan pembangunan nasional dilaksanakan berdasarkan prinsip ekonomi daerah dan pengaturan sumer daya nasional yang memberikan 
kesempatan bagi peningkatan demokrasi dan kinerja daerah untuk meningkatkan kesejahteraan daerah menuju masyarakat yang bebas korupsi.Dari pengertian diatas dapat disimpulkan bahwa pendapatan asli daerah dapat dikatakan sebagai penerimaan keuangan suatu daerah, dimana penerimaan daerah itu bersumber dari potensi-potensi yang ada di daerah tersebut.

Menurut Undang-Undang Nomor 33 Tahun 2004 tentang Perimbangan Keuangan Antara Pemerintah Pusat Dan Pemerintah Daerah, pendapatan asli daerah (PAD) bersumber dari :

a. Pajak Daerah. Pajak daerah adalahpemungutan pajak pada daerah menurut peraturan daerah yang dipergunakan dalam membiayai urusan rumah tangga daerah sebagai badan hukum publik.

b. Retribusi Daerah

Berdasarkan Undang-Undang Nomor 28 Tahun 2009 tentang pajak daerah dan retribusi daerah, menyebutkan bahwa retribusi daerah adalah pemungutan pajak pada daerah sebagai pembayaran atas jasa atau diberikan oleh pemerintah daerah untuk kepentingan orang pribadi atau badan.

c. Bagian Laba Badan Usaha Milik Daerah. Bagian badan usaha milik daerah ialah bagian keuntungan atau laba bersih dari perusahaan daerah yang merupakan badan usaha milik daerah. Sedangkan perusahaan daerah adalah perusahaan yang modalnya sebagian atau seluruhnya merupakan kekayaan milik daerah yang dipisahkan.

d. Lain-lain Pendapatan Daerah yang Sah. Merupakan penerimaan selain yang disebutkan diatas tapi sah. Penerimaan ini meliputi sewa, gedung dan tanah milik daerah dan penerimaan-penerimaan lain yang sah menurut undang-undang.

\section{Kendala Peningkatan Pajak Asli Daerah (PAD)}

Dalam rangka pelaksanaan otonomi daerah, pemerintah daerah diharapkan memiliki kemandirian yang lebih besar. Akan tetapi, masih banyak permasalahan yang dihadapi pemerintah daerah, terutama yang bersumber dari pendapatan asli daerah. Permasalahan tersebut disebabkan oleh kurangnya sumber daya manusia dalam mengelola penerimaan didaerah. Menurut Mardiasmo (2002) masalah yang dihadapi adalah :

1. Tingginya tingkat kebutuhan daerah yang tidak seimbang dengan penerimaan daerah.

2. Kualitas layanan publik yang masih lemah, sehingga produk layanan publik yang sebenarnya dapat dijual ke masyarakat direspon secara negatif. Keadaan tersebut menyebabkan masyarakat malas untuk taat dalam membayar pajak dan retribusi daerah.

3. Lembaga infrastruktur sarana dan prasarana umum yang kurang.

4. Berkurangnya dana bantuan dari pusat.

5. Belum diketahui potensi PAD yang mendekati potensi riil.

\section{Kerangka Pemikiran}

Dalam menghitung efektivitas, laju pertumbuhan, kontribusi, serta proyeksi pajak hotel diperlukan data mengenai taget dan realisasi pajak hotel dan pendapatan asli daerah melalui Laporan Realisasi Pendapatan Daerah Kota Padang dan Kota Bukittinggi yang diperoleh dari Badan Pendapatan Daerah Kota Padang dan Badan Pendapatan Daerah Kota Bukittinggi. Data yang telah dikumpulkan tersebut kemudian digunakan untuk menghitung efektivitas, laju pertumbuhan, kontribusi pajak hotel terhadap pendapatan asli daerah, dan proyeksi pajak hotel pada masa yang akan datang serta melakukan analisis komparatif terhadap pajak hotel. 


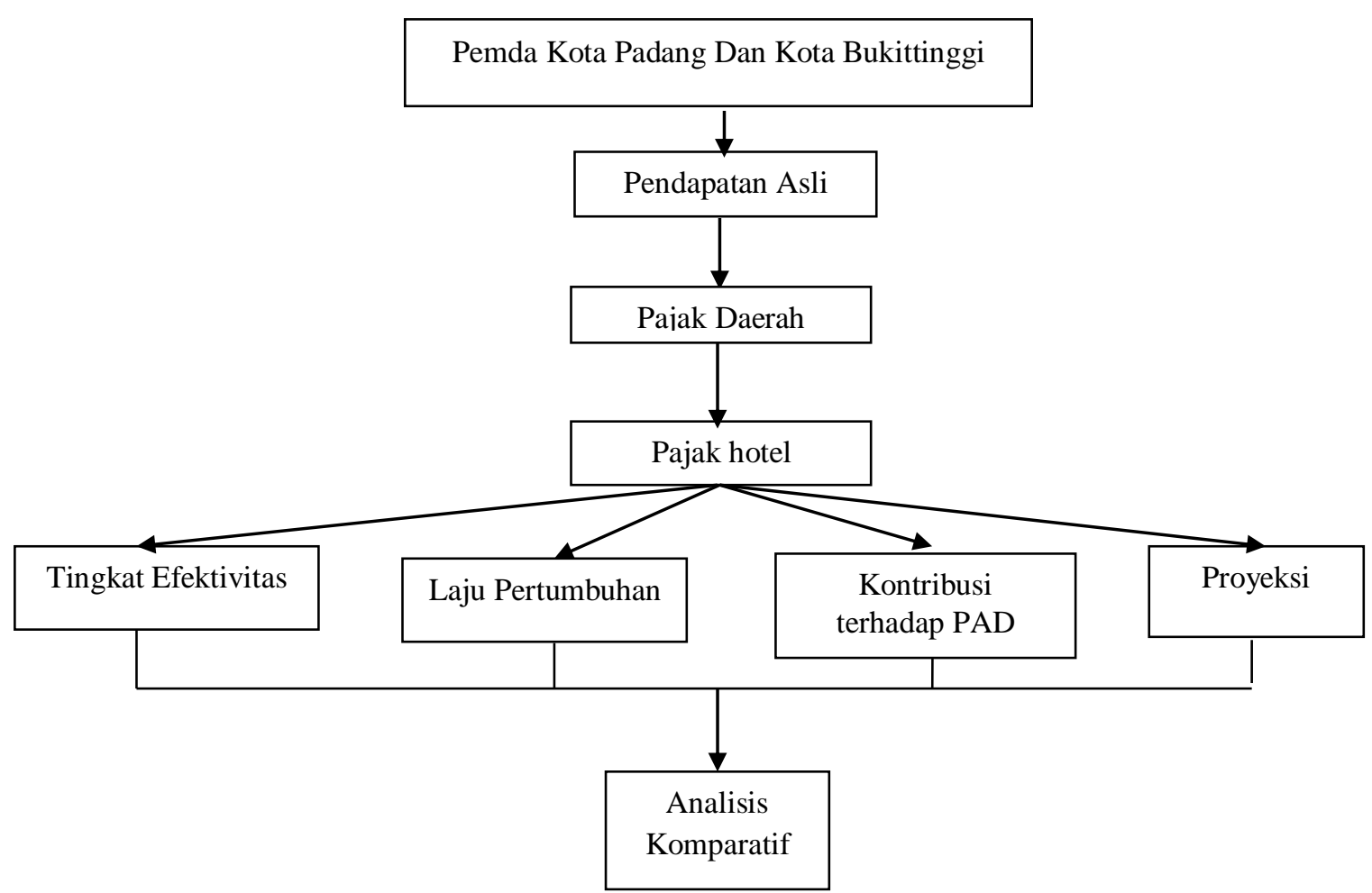

Gambar 1

\section{Kerangka Pemikiran}

\section{METODE PENELITIAN}

Penelitian ini merupakan jenis penelitian deskriptif dengan pendekatan kuantitatif dan kualitatif.

Sumber data yang digunakan berupa data sekunder dan data primer. Data sekunder adalah data yang mengacu kepada informasi yang dikumpulkan dari sumber yang telah ada (Sekaran, 2011). Data primer berupa informasi yang terkait dengan pajak daerah yang diperoleh dengan metode observasi, dokumentasi, maupun wawancara langsung dengan pihak yang terkait (Puttri, 2015).

Penelitian ini mengambil data di Badan Pendapatan Daerah Kota Padang dan Badan Pendapatan Daerah Kota Bukittinggi serta Badan Pusat Statistik Provinsi Sumatera Barat. Waktu penelitian dari bulan November 2019 sampai dengan selesai.

Adapun teknik pengumpulan data yang digunakan dalam penelitian ini, yaitu :
1. Dokumentasi. Pengumpulan data yang diperoleh dari dokumendokumen yang berkaitan dengan objek penelitian yang akan menunjang dan membuktikan hasil dari isi penelitian nantinya. Dalam hal ini data-data yang diperlukan diambil dari Badan Pendapatan Daerah Kota Padang dan Badan Pendapatan Daerah Kota Bukittinggi berupa Laporan Realisasi Pendapatan Daerah Kota Padang dan Kota Bukittinggi (2014 sampai 2018).

2. Studi KepustakaanSegala usaha yang dilakukan oleh peneliti untuk menghimpun informasi yang relevan dengan topik atau masalah yang akan diteliti. Informasi ini dapat diperoleh dari buku-buku ilmiah, laporan penelitian, karangan-karangan penelitian, dan sumber-sumber tertulis baik tercetak maupun elektronik lainnya

3. Wawancara. Wawancara merupakan teknik pengumpulan data yang dilakukan melalui tatap muka dan 
tanya jawab langsung antara pengumpul data maupun peneliti terhadap narasumber atau sumber data.

Metode analisis data yang akan digunakan berupa rasio efektivitas, analisis tingkat pertumbuhan, rasio kontribusi dan analisis proyeksi, serta analisis komparatif.

1. Rasio Efektivitas. Hubungan antara output dengan tujuan atau dapat juga dikatakan suatu ukuran sebera jauh tingkat output tertentu, kebijakan dan prosedur dari organisasi (Ardiles, 2015). Besarnya efektivitas pajak hotel dapat dihitung dengan rumus :

$$
\begin{gathered}
\text { Analisis Efektivitas }= \\
\frac{\text { Realisasi Penerimaan Pajak Hotel }}{\text { Target Pajak Hotel }} \times 100 \%
\end{gathered}
$$

Terdapat beberapa kriteria untuk menentukan apakah pajak hotel dapat dikatakan efektif atau tidak, kriteria tersebut ditunjukkan pada tabel 7 :

Tabel 7

\section{Kriteria Efektivitas}

\begin{tabular}{cc}
\hline Persentase & Kriteria \\
\hline$\geq 100 \%$ & Sangat Efektif \\
$90 \%-100 \%$ & Efektif \\
$80 \%-90 \%$ & Cukup Efektif \\
$60 \%-80 \%$ & Kurang Efektif \\
$<60 \%$ & Tidak Efektif \\
\hline
\end{tabular}

Sumber : Halim, 2007

2. Analisis Laju Pertumbuhan. Menurut (Halim, 2013) laju pertumbuhan menunjukkan seberapa besar kemampuan pemerintah daerah dalam mempertahankan dan meningkatkan keberhasilan daerah yang telah dicapainya dari periode sebelumnya ke periode berikutnya.

Ket :

$$
\mathrm{Gx}=\frac{\mathrm{Xt}-\mathrm{X}(\mathrm{t}-1)}{\mathrm{X}(\mathrm{t}-1)} \times 100 \%
$$

Gx : Laju pertumbuhan pajak hotel per tahun.

$\mathrm{Xt}$ : Realisasi penerimaan pajak hotel pada tahun tertentu.

$\mathrm{X}(\mathrm{t}-1)$ : Realisasi penerimaan pajak hotel pada tahun sebelumnya
Untuk menentukan apakah penerimaan pajak daerah dan retribusi daerah dapat dikatakan berhasil atau tidak, dapat ditentukan dengan kriteria yang ditunjukkan pada tabel 8:

\section{Tabel 8}

Kriteria Laju Pertumbuhan

\begin{tabular}{cc}
\hline Persentase & Kriteria \\
\hline$\leq 10 \%$ & Sangat Kurang \\
$10 \%-20 \%$ & Kurang \\
$20 \%-30 \%$ & Sedang \\
$30 \%-40 \%$ & Cukup Baik \\
$40 \%-50 \%$ & Baik \\
$\geq 50 \%$ & Sangat Baik \\
\hline
\end{tabular}

Sumber : Halim, 2007

3. Rasio Kontribusi. Menurut (Roziana, 2017)kontribusi adalah sesuatu yang diberikan bersama-sama dengan pihak lain untuk tujuan biaya atau kerugian tertentu atau bersama.

Analisis kontribusi $=$

$\frac{\text { Realisasi Penerimaan Pajak Hotel }}{\text { Realisasi Penerimaan PAD }} \times 100 \%$

Terdapat kriteria untuk menentukan apakah kontribusi pajak hotel terhadap PAD sudah baik atau belum, kriteria tersebut yang ditunjukkan pada tabel 9:

Tabel 9

Kriteria Kontribusi

\begin{tabular}{cc}
\hline Persentase & Kriteria \\
\hline$\leq 10 \%$ & Sangat Kurang \\
$10 \%-20 \%$ & Kurang \\
$20 \%-30 \%$ & Sedang \\
$30 \%-40 \%$ & Cukup Baik \\
$40 \%-50 \%$ & Baik \\
$\geq 50 \%$ & Sangat Baik \\
\hline
\end{tabular}

Sumber : Halim, 2007

4. Analisis Proyeksi. Menurut Susnawati dkk. (2014) secara umum, persamaan penaksiran atau proyeksi dengan teknik anuitas dapat ditulis sebagai berikut :

$$
\mathrm{Pt}=\mathrm{Po}(1+\mathrm{r})^{t}
$$

Untuk mendapatkan rata-rata pertumbuhannya (r) maka digunakan rumus sebagai berikut :

$$
r=\frac{(P t)_{t}^{1}-1}{P_{o}}
$$


Keterangan :

Po $=$ Penerimaan Pajak Hotel

Tahun Awal

$\mathrm{Pt}=$ Penerimaan Pajak Hotel Tahun

$\operatorname{tr}=$ Tingkat Pertumbuhan

$\mathrm{t}=$ Waktu/Tahun

5. Analisis Komparatif. Menurut Sugiyono (2014) komparatif adalah penelitian yang membandingkan keadaan satu variabel atau lebih pada dua atau lebih sampel yang berbeda, atau waktu yang berbeda. Penulis melakukan analisis komparatif dengan cara:

1. Peneliti akan melihat tingkat efektivitas pajak hotel di Kota Padang dan Kota Bukittinggi, lalu mengidentifikasi penyebab terjadinya perbedaan sertamenganalisis perbandingan.

2. Peneliti akan melihat laju pertumbuhan pajak hotel di Kota Padang dan Kota Bukittinggi, lalu mengidentifikasi penyebab terjadinya perbedaan sertamenganalisis perbandingan.

3. Peneliti akan melihat tingkat kontribusi pajak hotel di Kota Padang dan Kota Bukittinggi, lalu mengidentifikasi penyebab terjadinya perbedaan sertamenganalisis perbandingan.

4. Peneliti akan melihat tingkat proyeksi pajak hotel dimasa yang akan datang di Kota Padang dan Kota Bukittinggi, lalu mengidentifikasi penyebab terjadinya perbedaan serta menganalisis perbandingan.

\section{HASIL DAN PEMBAHASAN}

Analisis Efektivitas Penerimaan Pajak Hotel Kota Padang dan Kota Bukittinggi

Berdasarkan hasil penelitian dapat diketahui Efektivitas Penerimaan Pajak Hotel Kota Padang dan Kota Bukittinggi yang ditunjukkan dalam tabel 10 berikut ini:
Tabel 10

Tingkat Efektivitas Pajak Hotel Kota

Tahun 2014-2018

\begin{tabular}{ccc}
\hline Tahun & Kota Padang(\%) & Kota Bukittinggi(\%) \\
\hline 2014 & 107,49 & 95,49 \\
2015 & 81,84 & 100,51 \\
2016 & 101,08 & 81,49 \\
2017 & 105,74 & 85,58 \\
2018 & 107,55 & 93,51 \\
\hline Rata-rata & $\mathbf{1 0 0 , 7 4}$ & $\mathbf{9 1 , 3 2}$ \\
\hline
\end{tabular}

Sumber : Data diolah, 2020

Tabel 10 dapat dilihat bahwa tingkat efektivitas pajak hotel di Kota Padang lebih besar dari pada Kota Bukittinggi. Dimana rata-rata tingkat efektivitas pajak hotel Kota Padang sebesar $100,74 \%$ dengan kriteria "Sangat Efektif", dan Kota Bukittinggi dengan rata-rata tingkat efektivitas pajak hotel sebesar $91,32 \%$ dengan kriteria "Efektif". Penyebab terjadinya perbedaan tingkat efektivitas pajak hotel Kota Padang dengan Kota Bukittinggi dikarenakan :

a. Dilihat dari penerimaan realisasi pajak hotel di Kota Padang yang terus mengalami peningkatan dari tahun ke tahun, dimana pada tahun 2018 sebesar Rp.37.103.700.301. Sedangkan Kota Bukittinggi juga mengalami peningkatan dimana pada tahun 2018 sebesar Rp.13.819.121.537. Hal ini menandakan bahwa penerimaan realisasi pajak hotel di Kota Padang lebih besar dibandingkan dengan Kota Bukittinggi.

b. Berdasarkan data yang diperoleh dari Badan Pusat Statistik Provinsi Sumatera Barat, jumlah hotel yang ada di Kota Padang sampai tahun 2018 berjumlah 108 hotel, sedangkan di Kota Bukittinggi sampai tahun 2018 berjumlah 75 hotel. Ini menandakan bahwa jumlah hotel di Kota Padang lebih banyak dibandingkan dengan Kota Bukittinggi. 
c. Berdasarkan data yang diperoleh dari Badan Pusat Statistik Provinsi Sumatera Barat, jumlah wisatawan yanng berkunjung ke Kota Padang pada tahun 2018 sebanyak 5.147.635 orang, sedangkan di Kota Bukittinggi wisatawan yang berkunjung pada tahun 2018 sebanyak 4.047.135 orang. Jadi, Kota Padang merupakan kota yang banyak dikunjungi oleh wisatawan dibandingkan Kota Bukittinggi.

Laju Pertumbuhan Pajak Hotel di Kota Padang dan Kota Bukittinggi. Tabel 11

Tingkat Pertumbuhan Pajak Hotel Kota Padang dan Kota Bukittinggi Tahun 2014-2018

\begin{tabular}{ccc}
\hline Tahun & Kota Padang & Kota Bukittinggi \\
\hline 2014 & - & - \\
2015 & $-4,2$ & 5,26 \\
2016 & 28,71 & 14,02 \\
2017 & 19,47 & 22,41 \\
2018 & 17,94 & 9,26 \\
\hline Rata-rata & $\mathbf{1 5 , 4 8}$ & $\mathbf{1 2 , 7 4}$ \\
\hline
\end{tabular}

Sumber : Data diolah, 2020

Tabel 11 dapat dilihat bahwa tingkat pertumbuhan pajak hotel di Kota Padang lebih besar dibandingkan Kota Bukittinggi. Dimana rata-rata tingkat pertumbuhan pajak hotel Kota Padang sebesar $15,48 \%$ dengan kriteria "Kurang", dan Kota Bukittinggi dengan rata-rata tingkat pertumbuhan pajak hotel sebesar $12,74 \%$ dengan kriteria "Kurang".

Penyebab terjadinya perbedaan tingkat pertumbuhan pajak hotel antara Kota Padang dengan Kota Bukittinggi adalah perbedaan penerimaan pajak hotel, dimana Kota Padang mengalami peningkatan penerimaan pajak hotel yang lebih besar dari Kota Bukittinggi. Sehingga menyebabkan laju pertumbuhan realisasi pajak hotel di Kota Padang lebih tinggi dibandingkan dengan Kota Bukittinggi.

\section{Analisis Kontribusi Pajak Hotel Terhadap PAD Kota Padang dan Kota Bukittinggi.}

\section{Tabel 12}

Tingkat Kontribusi Pajak Hotel

Terhadap PAD Kota Padang dan Kota Bukittinggi

Tahun 2014-2018

\begin{tabular}{ccc}
\hline Tahun & Kota Padang (\%) & Kota Bukittinggi (\%) \\
\hline 2014 & 6,76 & 13,97 \\
2015 & 5,52 & 13,72 \\
2016 & 6,72 & 14,49 \\
2017 & 6,89 & 11,92 \\
2018 & 7,61 & 13,56 \\
\hline Rata-rata & $\mathbf{6 , 7 2}$ & $\mathbf{1 3 , 5 3}$ \\
\hline
\end{tabular}

Sumber : Data diolah, 2020

Pada tabel 12 dapat dilihat bahwa tingkat kontribusi pajak hotel Kota Bukittinggi lebih besar dibandingkan dengan Kota Padang. Dimana rata-rata tingkat kontribusi pajak hotel terhadap PAD Kota Bukittinggi sebesar 13,53\% dengan kriteria "Kurang", dan Kota Padang dengan rata-rata tingkat kontribusi pajak hotel terhadap PAD sebesar 6,72\% dengan kriteria "Sangat Kurang".

Penyebab terjadinya perbedaan tingkat kontribusi pajak hotel terhadap PAD Kota Padang dengan Kota Bukittinggi, karena penerimaan PAD dan realisasi pajak hotel Kota Padang dari tahun ke tahun mengalami peningkatan, tetapi realisasi pajak hotel tidak mendekati besarnya penerimaan PAD, dan mengakibatkan tingkat kontribusi pajak hotel terhadap PAD masih sangat kurang. Dilihat dari Kota Bukittinggi, penerimaan PAD dan realisasi pajak hotel mengalami peningkatan, tetapi PAD Kota Padang lebih tinggi dari pada Kota Bukittinggi, sehingga kotribusi pajak hotel Kota Bukittinggi lebih besar dari pada Kota Padang. 
Analisis Proyeksi Kota Padang dan Kota Bukittinggi.

Tabel 13

Proyeksi Pajak Hotel Kota Padang Dan Kota BukittinggiTahun 20202024

\begin{tabular}{ccc}
\hline Tahun & Kota Padang & Kota Bukittinggi \\
\hline 2020 & $49.392 .812 .258,4$ & 17.923 .928 .954 \\
2021 & $56.801 .734 .097,2$ & 20.254 .039 .178 \\
2022 & $65.321 .994 .211,8$ & $22.887 .064 .881,4$ \\
2023 & $75.120 .293 .343,5$ & $25.862 .383 .315,9$ \\
2024 & $86.388 .337 .345,1$ & 29.224 .493 .147 \\
\hline
\end{tabular}

Sumber: Data diolah, 2020

Pada tabel 13 dapat dilihat bahwa proyeksi penerimaan pajak hotel di Kota Padang dan Kota Bukittinggi dari tahun 2020 sampai 2024 mengalami peningkatansetiap tahunnya. Dimana proyeksi penerimaan Kota Padang lebih besar dibandingkan dengan Kota Bukittinggi.

Penyebab terjadinya perbedaan proyeksi di Kota Padang dengan Kota Bukittinggi dikarenakanpotensi yang dimiliki oleh Kota Padang lebih besar seperti diperkirakan jumlah hotel yang ada di Kota Padang akan semakin bertambah banyak dibandingkan dengan Kota Bukittinggi, dan kunjungan wisatawan ke Kota Padang akan semakin bertambah dari tahun sebelumnya diakibatkan karena sudah banyak tempat wisata yang baru dibangun oleh Pemerintah Kota Padang.

Pembahasan

\section{Tingkat Efektivitas Pajak Hotel Kota Padang Dan Kota Bukittinggi}

Dari perhitungan yang dilakukan bahwa tingkat efektivitas dari realisasi pajak hotel Kota Padang tahun 2014 sampai 2018 dikatakan sangat efektif, dikarenakan terjadinya peningkatan realisasi pajak hotel serta tercapainya target pajak hotel yang ditetapkan oleh Pemerintah Kota Bukittinggi dari tahun 2014 sampai 2018. Jika dilihat dari jumlah hotel yang ada, jumlah hotel Kota Padang mengalami peningkatan setiap tahunnya. Serta jumlah wisatawan yang datang ke Kota Padang juga mengalami peningkatan setiap tahunnya. Tingkat efektivitas dari realisasi pajak hotel Kota Bukittinggi tahun 2014 sampai 2018 dikatakan efektif, dikarenakan terjadinya peningkatan realisasi pajak hotel dari tahun 2014 sampai 2018 tetapi tidak dapat mencapai target yang telah ditetapkan oleh Pemerintah Kota Bukittinggi, serta jumlah hotel Kota Bukittinggi juga mengalami peningkatan setiap tahunnya dengan jumlah wisatawan yang datang ke Kota Bukittinggi bertambah, tetapi tidak sebanyak jumlah wisatawan yang datang ke Kota Padang.

\section{Tingkat Pertumbuhan Pajak Hotel Kota Padang Dan Kota Bukittinggi}

Dari perhitungan yang dilakukan bahwa tingkat pertumbuhan pajak hotel Kota Padang tahun 2014 sampai 2018 dikatakan kurang, walaupun realisasi pajak hotel Kota Padang mengalami peningkatan dari tahun ke tahun, hal ini belum menandakan bahwa laju pertumbuhan pajak hotel telah berhasil. Tingkat pertumbuhan pajak hotel Kota Bukittinggi tahun 2014 sampai 2018 dikatakan kurang, walaupun realisasi pajak hotel mengalami peningkatan setiap tahunnya, tetapi peneriman pajak hotel tidak jauh besar dari penerimaan tahun sebelumnya.

\section{Tingkat Kontribusi Pajak Hotel Terhadap PAD Kota Padang Dan Kota Bukittinggi}

Dari perhitungan yang dilakukan bahwa kontribusi pajak hotel terhadap Pendapatan Asli Daerah (PAD) Kota Padang tahun 2014 sampai 2018 mengalami peningkatan dengan kriteria kontribusi pajak hotel sangat kurang, walaupun penerimaan pajak hotel dan penerimaan PAD Kota Padang dari tahun ke tahun mengalami peningkatan, tetapi penerimaan pajak hotel jauh lebih rendah dari penerimaan $\mathrm{PAD}$, sehingga 
menyebabkan kontribusi pajak hotel sangat kurang terhadap PAD Kota Padang. Kontribusi pajak hotel terhadap Pendapatan Asli Daerah (PAD) Kota Bukittinggi tahun 2014 sampai 2018 mengalami fluktuasi dengan kriteria kontribusi pajak hotel kurang,hal ini dikarenakan penerimaan pajak hotel Kota Bukittinggi belum maksimal dibandingkan penerimaan PAD Kota Bukittinggi.

\section{Tingkat Proyeksi Pajak Hotel Kota Padang Dan Kota Bukittinggi Tahun 2020 Sampai 2024}

Dari perhitungan yang dilakukan bahwa diperkirakan proyeksi penerimaan pajak hotel Kota Padang akan mengalami peningkatan selama tahun 2020 sampai 2024. Dimana diperkirakan pembangunan hotel yang ada di Kota Padang akan mengalami peningkatan akibat dari wisatawan yang datang semakin bertambah serta maraknya tempat wisata. Proyeksi penerimaan pajak hotel Kota Bukittinggi akan mengalami peningkatan, karena Kota Bukittinggi dikenal sebagai kota wisata yang akan menarik para wisatawan untuk berkunjung. Dengan begitu, pembangunan hotel di Kota Bukittinggi akan semakin meningkat.

\section{Analisis Komparatif Kota Padang Dengan Kota Bukittinggi}

1. Dilihat dari tingkat efektivitas, tingkat efektivitas pajak hotel di Kota Padang lebih besar dari pada Kota Bukittinggi. Dimana efektivitas pajak hotel Kota Padang dengan kriteria sangat efektif, dan Kota Bukittinggi efektivitas pajak hotel dengan kriteria efektif. Penyebab perbedaannyakarena realisasi pajak hotel Kota Padang lebih besar, seta jumlah hotel yang ada di Kota Padang lebih banyak dibandingkan Kota Bukittinggi.

2. Dilihat dari tingkat pertumbuhan, tingkat pertumbuhan pajak hotel di
Kota Padang lebih besar dibandingkan Kota Bukittinggi. Dimana pertumbuhan pajak hotel Kota Padang dengan kriteria kurang, dan Kota Bukittinggi dengan pertumbuhan pajak hotel dengan kriteria kurang. Penyebab terjadinya perbedaan karena penerimaan pajak hotel Kota Padang lebih besar.

3. Dilihat dari tingkat kontribusi, tingkat kontribusi pajak hotel Kota Bukittinggi lebih besar dibandingkan dengan Kota Padang. Dimana kontribusi pajak hotel Kota Bukittinggi masih kurang terhadap PAD Kota Bukittinggi, dan kontribusi pajak hotel Kota Padang terhadap PAD Kota Padang dikatakan sangat kurang.

4. Dilihat dari proyeksi pajak hotel, proyeksi penerimaan pajak hotel di Kota Padang dan Kota Bukittinggi dari tahun 2020 sampai 2024 mengalami peningkatan setiap tahunnya. Dimana proyeksi penerimaan Kota Padang lebih besar dibandingkan dengan Kota Bukittinggi, dilihat dari lebih banyaknya wisatawan yang berkunjung ke Kota Padang, membuat Pemerintah Kota Padang lebih meningkatkan objek wisata serta pembangunan hotel di Kota Padang.

\section{Adapun kendala yang dihadapi Pemerintah Kota Padang dan Kota Bukittinggi dalam proses pemungutan pajak hotel tahun 2014 sampai 2018.}

Pemerintah Kota Padang dan Kota Bukittinggi menggunakan self assessment system dalam pemungutan pajak yaitu wajib pajak menetapkan, melaporkan dan menyetorkan sendiri pajaknya. Mekanisme dalam pemungutan pajak adalah wajib pajak melakukan pelaporan melalui Sistem Operasional Penerimaan Pajak Daerah (SOPD), disana wajib pajak menginput 
berapa omzet yang diterima perbulan yang langsung dikenakan tarif $10 \%$ dalam hal penginputan. Setelah itu keluar nilai pajak yang harus disetorkan, pembayaran dilakukan di dua bank (Bank Nagari dan BNI) dan 1 pos yang ada di Indonesia. Kemudian keluarlah bukti setoran, untuk mendapatkan angka yang tertera di bukti setoran maka hotel tersebut harus melakukan pemungutan pajak dari pengunjung yang sudah menikmati fasilitas yang sudah diberikan. Pajak yang sudah dibayarkan oleh wajib pajak masuk ke kas daerah.

\section{Tabel 14}

\section{Kendala Dan Upaya Optimalisasi} Penerimaan Pajak Hotel

\begin{tabular}{|c|c|c|}
\hline No. & $\begin{array}{l}\text { Hambatan- } \\
\text { hambatan }\end{array}$ & $\begin{array}{c}\text { Upaya Optimalisasi Penerimaan } \\
\text { Pajak Hotel }\end{array}$ \\
\hline 1. & $\begin{array}{l}\text { Adanya wajib pajak } \\
\text { yang tidak tertib } \\
\text { dalam pembayaran } \\
\text { pajak. }\end{array}$ & $\begin{array}{l}\text { 1. Melakukan penagihan pajak } \\
\text { dengan mendatangi langsung } \\
\text { wajib pajak yang belum } \\
\text { membayar pajak. }\end{array}$ \\
\hline \multirow{4}{*}{2.} & & $\begin{array}{l}\text { 2. Menerbitkan Surat Teguran } \\
\text { apabila wajib pajak tidak melunasi } \\
\text { hutang pajak } 7 \text { hari setelah jatuh } \\
\text { tempo pembayaran. } \\
\text { 3. Menerbitkan Surat Tagihan Pajak } \\
\text { Daerah (STPD). } \\
\text { 4. Koordinasi dengan instansi terkait } \\
\text { antara Badan Pendapatan Daerah } \\
\text { dengan Kantor Pelayanan Pajak }\end{array}$ \\
\hline & $\begin{array}{l}\text { Adanya wajib pajak } \\
\text { yang tidak } \\
\text { melaporkan omzet } \\
\text { yang sebenarnya. }\end{array}$ & $\begin{array}{l}\text { 1. Memasangkan Tapping Box(alat } \\
\text { untuk mendeteksi transaksi secara } \\
\text { online) di komputer yang } \\
\text { menginput terjadinya transaksi. }\end{array}$ \\
\hline & & $\begin{array}{l}\text { 2. Melaksanakan monitoring di } \\
\text { lapangan dengan mengawasi } \\
\text { langsung hotel tersebut selama } \\
\text { beberapa hari, untuk melihat } \\
\text { menghitung besarnya omzet serta } \\
\text { membandingkan besarnya } \\
\text { penghasilan dengan tingkat } \\
\text { keramaian. }\end{array}$ \\
\hline & & $\begin{array}{l}\text { 3. Melaksanakan pemeriksaan wajib } \\
\text { pajak. }\end{array}$ \\
\hline 3. & $\begin{array}{l}\text { Adanya calon wajib } \\
\text { pajak baru yang } \\
\text { belum terdaftar. }\end{array}$ & $\begin{array}{l}\text { Mendatangi hotel baru tersebut, } \\
\text { kemudian di daftarkan sebagai wajib } \\
\text { pajak dan melaksanakan } \\
\text { kewajibannya. }\end{array}$ \\
\hline
\end{tabular}

Pada tabel 14 dapat dilihat kendala yang dihadapi oleh Pemerintah Kota Padang dan Pemerintah Kota Bukittinggi dalam pemungutan pajak hotel hampir memiliki kesamaan kendala, tetapi ada kendala lain yang dihadapi oleh Pemerintah Kota
Bukittinggi dalam proses pemungutan pajak hotel, seperti:

a. Masih belum memadainya pemerintah daerah Kota Bukittinggi dalam pemungutan pajak hotel, dan ini akan segera dievaluasi secara sungguh-sungguh oleh pemerintah daerah Kota Bukittinggi dalam upaya peningkatan pelayanan dan fasilitas kepada masyarakat.

b. Masih kurang efektif dan efisien target untuk mencapai realita dalam pemenuhan kebutuhan masyarakat.

c. Ketidaksiapan Pemerintah Kota Bukittinggi dalam menggali potensi pajak hotel, karena ini Pemerintah Daerah Kota Bukittinggi akan lebih mempersiapkan dan merencanakan pengglian potensi pajak hotel yang lebih maksimal.

\section{SIMPULAN}

dan pembahasan pada bab sebelumnya, maka dapat diambil kesimpulan sebagai berikut:

1. Tingkat efektivitas dari realisasi pajak hotel Kota Padang tahun 2014 sampai 2018 bisa dikatakan "Sangat Efektif" dengan rata-rata tingkat efektivitas sebesar 100,74\%.Tingkat efektivitas dari realisasi pajak hotel Kota Bukittinggi tahun 2014 sampai 2018 bisa dikatakan "Efektif" dengan ratarata tingkat efektif sebesar $91,32 \%$.

2. Tingkat pertumbuhan pajak hotel Kota Padang tahun 2014 sampai 2018 dikatakan "Kurang" dengan rata-rata tingkat pertumbuhan pajak hotel sebesar $15,48 \%$. Sedangkan tingkat pertumbuhan pajak hotel Kota Bukittinggi tahun 2014 sampai 2018 dikatakan "Kurang" dengan rata-rata tingkat pertumbuhan pajak hotel sebesar $12,74 \%$.

3. Kontribusi pajak hotel terhadap Pendapatan Asli Daerah (PAD) Kota Padang tahun 2014 sampai 2018 mengalami peningkatan dengan 
kriteria kontribusi pajak hotel "Sangat Kurang" dengan rata-rata kontribusi pajak hotel sebesar 6,7\%. Kontribusi pajak hotel terhadap Pendapatan Asli Daerah (PAD) Kota Bukittinggi tahun 2014 sampai 2018 mengalami fluktuasi dengan kriteria kontribusi pajak hotel "Kurang" dengan rata-rata kontribusi pajak hotel sebesar $13,53 \%$.

4. Diperkirakan proyeksi penerimaan pajak hotel Kota Padang dan Kota Bukittinggi akan mengalami peningkatan selama tahun 2020 sampai 2024, dengan potensi yang lebih besar dari tahun sebelumnya.

5. Dari analisis komparatif yang dilakukan antara antara Kota Padang dengan Kota Bukittinggi, dapat disimpulkan:

a. Dilihat dari tingkat efektivitas, tingkat efektivitas pajak hotel di Kota Padang lebih besar dari pada Kota Bukittinggi. Dimana efektivitas pajak hotel dengan kriteria "Sangat Efektif', dan Kota Bukittinggi dengan efektivitas pajak hotel dengan kriteria "Efektif".

b.Dilihat dari tingkat pertumbuhan, tingkat pertumbuhan pajak hotel di Kota Padang lebih besar dibandingkan Kota Bukittinggi. Dimana pertumbuhan pajak hotel Kota Padang dengan kriteria "Kurang", dan Kota Bukittinggi dengan tingkat pertumbuhan pajak hotel dengan kriteria "Kurang".

c. Dilihat dari tingkat kontribusi, tingkat kontribusi pajak hotel Kota Bukittinggi lebih besar dibandingkan dengan Kota Padang. Dimana kontribusi pajak hotel terhadap PAD Kota Bukittinggi dengan kriteria "Kurang", dan Kota Padang kontribusi pajak hotel terhadap PAD dengan kriteria "Sangat Kurang".

d.Dilihat dari proyeksi pajak hotel, proyeksi penerimaan pajak hotel di
Kota Padang dan Kota Bukittinggi dari tahun 2020 sampai 2024 mengalami peningkatan setiap tahunnya. Dimana proyeksi penerimaan Kota Padang lebih besar dibandingkan dengan Kota Bukittinggi.

6. Kendala yang dihadapi Pemerintah Kota Padang dan Kota Bukittinggi dalam meningkatkan pajak hotel hampir memiliki kesamaan yaitu adanya wajib pajak yang tidak tertib dalam membayar pajak, adanya wajib pajak yang tidak melaporkan omzet yang sebenarnya dan adanya calon wajib pajak baru yang belum terdaftar sebagai wajib pajak Pemerintah Kota Padang dan Kota Bukittinggi. Dengan adanya beberapa kendala yang dihadapi, namun Pemerintah Kota Padang dan Kota Bukittinggi mempunyai upaya yang dijalankan untuk mengatasi segala kendala seperti dengan melakukan penagihan pajak dengan mendatangi langsung wajib pajak yang belum membayar pajak, menerbitkan surat teguran, menerbitkan Surat Tagihan Pajak Daerah (STPD), memasangkan Tapping Box (alat untuk mendeteksi transaksi secara online) di komputer yang menginput terjadinya transaksi, serta mendatangi hotel baru untuk didaftarkan sebagai wajib pajak dan melaksanakan kewajibannya. Adapun kendala lain yang dihadapi oleh Pemerintah Kota Bukittinggi diantaranya masih belum memadainya pemerintah daerah Kota Bukittinggi dalam pemungutan pajak hotel, dan ini akan segera dievaluasi secara sungguh-sungguh oleh pemerintah daerah Kota Bukittinggi dalam upaya peningkatan pelayanan dan fasilitas kepada masyarakat, masih kurang efektif dan efisien target untuk mencapai realita dalam pemenuhan kebutuhan masyarakat, serta ketidaksiapan Pemerintah Kota 
Bukittinggi dalam menggali potensi pajak hotel, karena ini Pemerintah Daerah Kota Bukittinggi akan lebih mempersiapkan dan merencanakan pengglian potensi pajak hotel yang lebih maksimal.

Berdasarkan hasil penelitian, ada beberapa saran yang dapat diberikan, antara lain:

\section{Bagi Pemerintah Kota Padang dan Kota Bukittinggi}

a. Sebaiknya Pemerintah Kota Padang Kota Bukittinggi lebih meningkatkan sosialisasi kepada masyarakat mengenai pajak hotel agar terciptanya kesadaran sehingga masyarakat menjalankan kewajibannya demi meningkatkan penerimaan pajak hotel di Kota Padang Kota Bukittinggi.

b. Kontribusi pajak hotel masih sangat kurang sehingga Pemerintah Kota Padang Kota Bukittinggi harus lebih memperhatikan dan mencari solusi atau cara dalam meningkatkan kontribusi dari pajak hotel dengan cara menggali potensi yang ada.

c. Pemerintah Kota Padang Kota Bukittinggi diharapkan lebih meningkatkan lagi fungsi kontrol dari pemerintah terhadap instansi terkait demi terciptanya kinerja yang lebih baik lagi untuk tahun selanjutnya dapat memberikan hasil dari penerimaan pajak hotel yang lebih optimal.

d. Pemerintah Kota Padang Kota Bukittinggi diharapkan untuk mengkaji lagi dalam hal penetapan target pajak hotel tahun berikutnya agar tidak lebih rendah dari realisasi tahun sebelumnya. Serta mengoptimalkan kriteria untuk pajak hotel terhadap Pendapatan Asli Daerah (PAD).

e. Pemerintah Kota Padang Kota Bukittinggi sebaiknya mempertegas kembali sanksi yang dapat diberikan kepada wajib pajak yang membuka hotel, apabila wajib pajak secara sengaja lalai dalam melakukan pembayaran pajak. Hal ini dipelukan agar penerimaan pajak daerah Kota Padang dan Kota Bukittinggi dapat terserap secara optimal.

Bagi Peneliti Selanjutnya

Diharapkan dapat memperluas objek penelitian pada kota/kabupaten yang ada di Provinsi Sumatera Barat serta menambah variael penelitian, bukan hanya dari pajak hotel tetapi dapat melakukan penelitian dari sektor-sektor lain yang sangat berpengaruh terhadap Pendapatan Asli Daerah (PAD) Kota Padang dan Kota Bukittinggi, seperti Pajak Restoran, Pajak Hiburan, Pajak Penerangan Jalan, Pajak Reklame, Pajak Penerangan Jalan, dan pajak lainnya.

Keterbatasan Penelitian

Didalam proses pembuatan skripsi ini, peneliti memiliki keterbatasan terkait objek yang diteliti. Keterbatasan penulis tersebut sebagai berikut:

1.Penulis membandingkan efektivitas dan kontribusi pajak hotel terhadap Pendapatan Asli Daerah hanya 5 (lima) tahun saja, yaitu dari tahun 2014 sampai 2018.

2. Penulis hanya meneliti 1 (satu) komponen sektor pajak daerah yaitu pajak hotel.

3. Penulis hanya meneliti 2 (dua) kota yang ada di Provinsi Sumatera Barat yaitu Kota Padang dan Kota Bukittinggi.

\section{DAFTAR PUSTAKA}

Ardiles. (2015). Analisis Potensi Dan Kontribusi Pajak Hotel Terhadap Pendapatan Asli Daerah Pemerintah Kota Padang (Studi Kasus Di Dinas Pengelolaan Keuangan Dan Aset Kota Padang). Program Studi Akuntansi Fakultas Ekonomi Universitas Negeri Padang, 151, 10-17. Https://Doi.Org/10.1145/3132847. 3132886. 
Fitra, H. (2016). Pengaruh Pajak Daerah Dan Retribusi Daerah Terhadap Pendapatan Asli Daerah (PAD) Di Kota Padang Setelah Dikeluarkannya Undang-Undang Otonomi Daerah. Jurnal Praktik Bisnis, Volume 5, Nomor 1,Mei 2016, Issn 2302-9242, 1(1), 87. Https://Doi.Org/10.25124/Jaf.V1i 01.902.

Halim, A. (2013). Akuntansi Sektor Publik, Akuntansi Keuangan Daerah. Jakarta. Salemba Empat.

Kurniawan, N. A. C., Harimurti, F., \& Astuti, D. S. P. (2016). Analisis Efektivitas Dan Kontribusi Pajak Hotel Terhadap Pendapatan Asli Daerah Kota Surakarta Tahun 2010 - 2014. Jurnal Akuntansi Dan Sistem Teknologi Informasi Vol. 12 No. 3 September 2016: 372 - 381, 12(Chilcot), 14-15.

Nini, \& Adli, M. F. (2018). Analisis Kontribusi Pajak Hotel Dan Pajak Restoranterhadap Pendapatan Asli Daerah (Pad) Kota Padang Periode 2012-2016 (Studi Di Badan Pendapatan Daerah Kota Padang). Menara Ilmu Vol. Xii, No.11 Oktober 2018 Tahun, Xii(11), 80-93.

Mahmudi. 2009. Manajemen Keuangan Daerah. Jakarta : Penerbit Erlangga.

Mardiasmo. 2002. Akuntansi Sektor Publik. Yogyakarta. Penerbit Andi Offset.

Pangerapan, T. R., Karamoy, H., \& Alexander, S. W. (2018). Analisis Efektivitas Dan Kontribusi Pajak Hotel Terhadap Pendapatan Asli Daerah Kabupaten Halmahera Utara. Jurnal Riset Akuntansi Going Concern 13(3), 2018, 165173, 13(4), 165-173. Https://Doi.Org/10.32400/Gc.13.0 3.20050.2018.

Pujiasih, R., \& Wardani, D. K. (2014). Analisis Potensi, Efektifitas Dan
Kontribusi Pajak Hotel Terhadap Pendapatan Asli Daerah Kabupaten Sleman. Jurnal Akuntansi. Vol.2 No.2 Desember 2014., 2(2), 43-54.

Putra, I. M. (2017). Perpajakan. Yogyakarta. Quadrant.

Puttri, D. (2015). Analisis Potensi Penerimaan Pajak Daerah Kota Bukittinggi. Fakultas Ekonomi Universitas Bung Hatta.

Rabunusa, M., Nangoi, G. B., \& Suwetja, I. G. (2018). Analisis Efektivitas Penerimaan Dan Kontribusi Pajak Hotel Terhadap Pendapatan Asli Daerah Kota Tomohon (Pada Badan Keuangan Daerah Kota Tomohon). Jurnal Riset Akuntansi Going Concern 13(2), 2018, 68-77, 13(2), 68-77.

Resmi, S. (2016). Perpajakan Teori Dan Kasus. Jakarta. Salemba Empat.

Roziana, E. (2017). Analisis Efektivitas Dan Kontribusi Pajak Daerah Terhadap Pendapatan Asli Daerah Eks-Karesidenan Surakarta. Program Studi Akuntansi Fakultas Ekonomi Dan Bisnis Universitas Muhammadiyah Surakarta.

Sartika, D., Ulfa, A., \& Ilyas, A. (2019). Analisis Potensi Penerimaan Pajak Daerah Dan Retribusi Daerah Terhadap Pendapatan Asli Daerah (PAD) Kabupaten/Kota Di Provinsi Sumatera Barat. Jurnal Ekonomi \& Bisnis Dharma Andalas Volume 21 No 1, Januari 2019, 21(1), 32-53.

Sekaran, Uma. (2011). Research Methods for Business Edisi 1 and 2. Jakarta. Salemba Empat.

Sugiyono. (2014). Metode Penelitian Pendidikan Pendekatan Kuantitatif, Kualitatif, dan $R \& D$. Bandung. Alfabeta.

Susnawati, dkk. 2014. Analisis Potensi Pajak Daerah Sebagai Sumber 
Pendapatan Asli Daerah Do Kota Metro. Jep-Vol.3. Universitas Lampung.

Syafitri, D. I. (2016). Analisis Pertumbuhan Dan Kontribusi Pajak Daerah, Retribusi Daerah, Dan Lain-Lain PAD Yang Sah Terhadap Pendapatan Asli Daerah (Studi Pada Kabupaten/Kota Di Provinsi Jawa Tengah). Program Studi Akuntansi Fakultas Ekonomi Dan Bisnis Universitas Muhammadiyah Surakarta.

Toding, R. B. (2016). Analisis Potensi Dan Efektivitas Pemungutan Pajak Hotel Dalam Meningkatkan Pendapatan Asli Daerah Kota Palangka Raya. Jurnal Emba Vol.4 No.1 Maret 2016, Hal. 214222, 4(1), 214-222.

Undang-Undang Nomor 33 Tahun 2004 Tentang Perimbangan Keuangan Antara Pemerintah Pusat Dan Pemerintah Daerah.

Peraturan Daerah Kota Padang Nomor 8 Tahun 2011 Tentang Pajak Hotel. Undang-Undang Nomor 28 Tahun 2009 Tentang Pajak Daerah Dan Retribusi Daerah.

Undang-Undang Nomor 28 Tahun 2007 Tentang Ketentuan Umum Dan Tata Cara Perpajakan.

Undang-Undang Nomor 34 Tahun 2000 Tentang Tarif Maksimal Pajak Daerah.

Wibowo, A. P. (2018). Analisis Efektivitas, Kontribusi, Potensi Pajak Daerah Dan Retribusi Daerah Terhadap Pendapatan Asli Daerah (Pad). Fakultas Ekonomi Universitas Widya Dharma

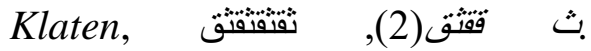
Https://Doi.Org/10.1051/Matecco nf/201712107005. 